\title{
ПЕДАГОГИЧЕСКИЕ ПОДХОДЫ К РЕШЕНИЮ ПРОБЛЕМЫ ПРОТИВОДЕЙСТВИЯ УГРОЗАМ И РИСКАМ В СЕТИ ИНТЕРНЕТ ${ }^{1}$
}

\section{PEDAGOGICAL APPROACHES TO SOLVING THE PROBLEM OF COUNTERACTING THREATS AND RISKS IN THE INTERNET \\ V. Kureychik V. Pisarenko}

Summary: This work is devoted to the problem of considering the pedagogical aspects of countering threats and risks in the Internet. The article discusses the definitions of "risk", "threat", classification of risks and threats, their types. Data on user activity on the Internet are provided. The risks and threats that pose the greatest danger to youth are analyzed.

Keywords: risk, threat, Internet, user, security, communication.
Курейчик Виктор Михайлович

Д.т.н., профессор, Институт компьютерных технологий и информационной безопасности Южного федерального университета, г. Таганрог vmrureychik@sfedu.ru

Писаренко Вероника Игоревна

Д.п.н., профессор, Институт управления в экономических, экологических и сочиальных системах Южного федерального университета, г. Таганрог, vero19671993@gmail.com

Аннотация: Данная работа посвящена проблеме рассмотрению педагогических аспектов противодействия угрозам и рискам в сети Интернет. В статье рассматриваются определения понятий «риск», «угроза», классификации рисков и угр03, их типы и виды. Приводятся данные 06 активности пользователей в сети Интернет. Анализируются риски и угрозы, представляющие наибольшую опасность для молодежи.

Ключевые слова: риск, угроза, сеть Интернет, пользователь, безопасность, коммуникация.

муникаций, коммуникативных технологий, с совокупностью виртуальных миров, которые сегодня становятся реальностью, характеризующейся разнообразием, которому свойственны вариативность, неопределенность и нелинейность развития. Именно поэтому «родилась особая матрица взаимопроникающих миров, в которой мы все существуем» [1, с.116].

Одним из элементов этой «матрицы миров» является сеть Интернет, альтернативу которой по популярности сложно найти. По состоянию на 1 января 2019 г. в мире насчитывалось 4100667287 интернет-пользователей. В 2014 году эта цифра равнялась 3,42 млрд пользователей. Наибольшее количество интернет-пользователей попрежнему в Азии - 49 \% от общего количества, на втором месте Европа (16,8\%), за которой следует Африка (11\%) и Карибский бассейн (10,4\%). Оставшиеся 12,8\% неравномерным образом распределены по миру. В Азии самым активным остается Китай. Следом за ним по количеству активных пользователей сети идет США с 320 млн человек, Россия со 109.5 млн и Латинская Америка/Карибский бассейн с 18.5 млн [3].

В Северной Америке самый высокий уровень использования интернета: $88.1 \%$ населения ежедневно выходят в сеть. В Европе этот показатель составляет $85.2 \%$, в Рос-

Исследование выполнено при финансовой поддержке РФФИ в рамках научного проекта № 18-29-22019 


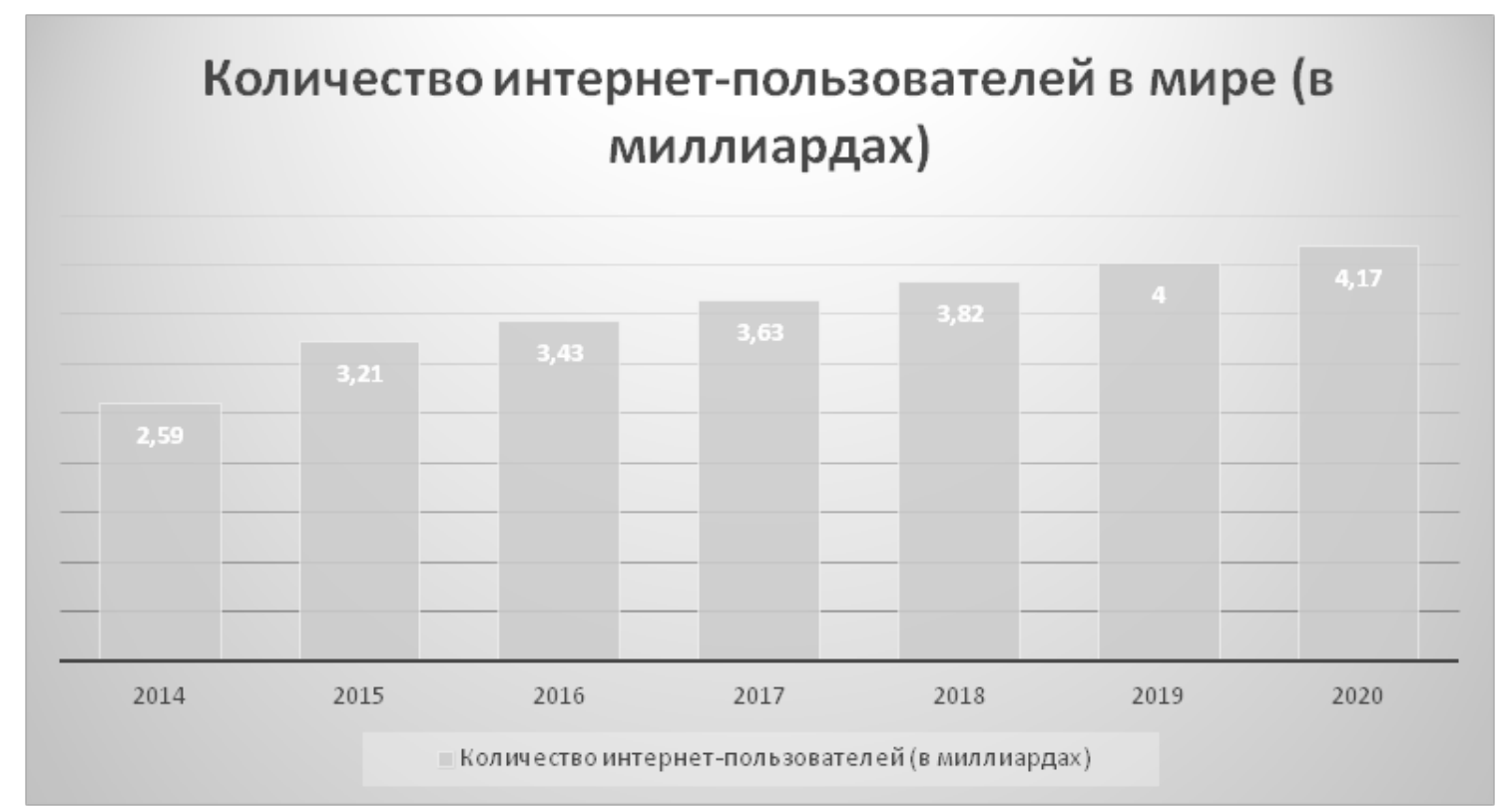

Рис.1. Диаграмма зависимости количества интернет-пользователей от года

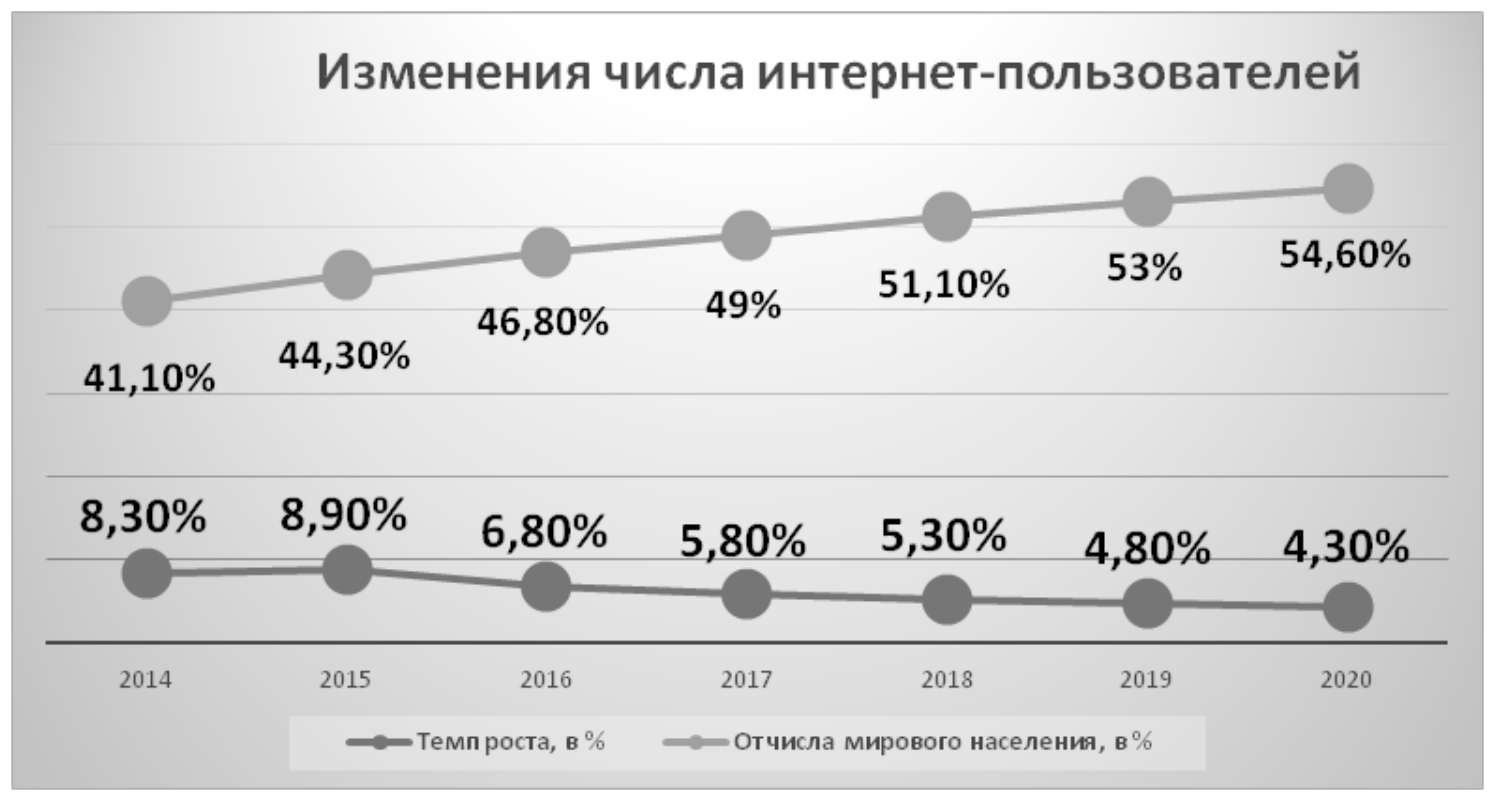

Рис. 2. График процентной зависимости числа интернет-пользователей от года

сии - 75.4\%. В среднем по миру - 55.1\% (по сравнению с 35\% в 2013 году). Еще можно отметить Фолклендские острова и Исландию, где в сеть регулярно заходит 99.3\% и 99.0\% жителей соответственно, но это объясняется их малой заселенностью: 2919 и 337780 человек. В январе 2019 года интернет насчитывал более 1.94 миллиарда сайтов. Первый в мире сайт в привычном для нас понимании (hhtp (s)://www.) появился в 1990 году. Google обрабатывает более 7 миллиардов поисковых запросов по всему миру в день: иногда эта цифра достигает 10 миллиардов. 15\% из этих запросов никогда не искали в Google раньше.

Google Chrome доминирует среди пользователей по всему миру - с долей 61.77\%. Другие браузеры распределены по аудитории так: Safari (15.91\%), Firefox (4.92\%), Opera (3.15\%) и Internet Explorer (2.81\%).

Увеличению числа пользователей сети Интернет способствовало появление мобильных устройств 53\% пользователей заходят в интернет с мобильных устройств. В 2018 году на мобильный трафик приходилось $48.2 \%$.

Рис.3 представляет данные, позволяющие сравнить использование смартфонов, компьютеров и планшетов.

Ежедневно в сети Интернет публикуется более 4 мил- 


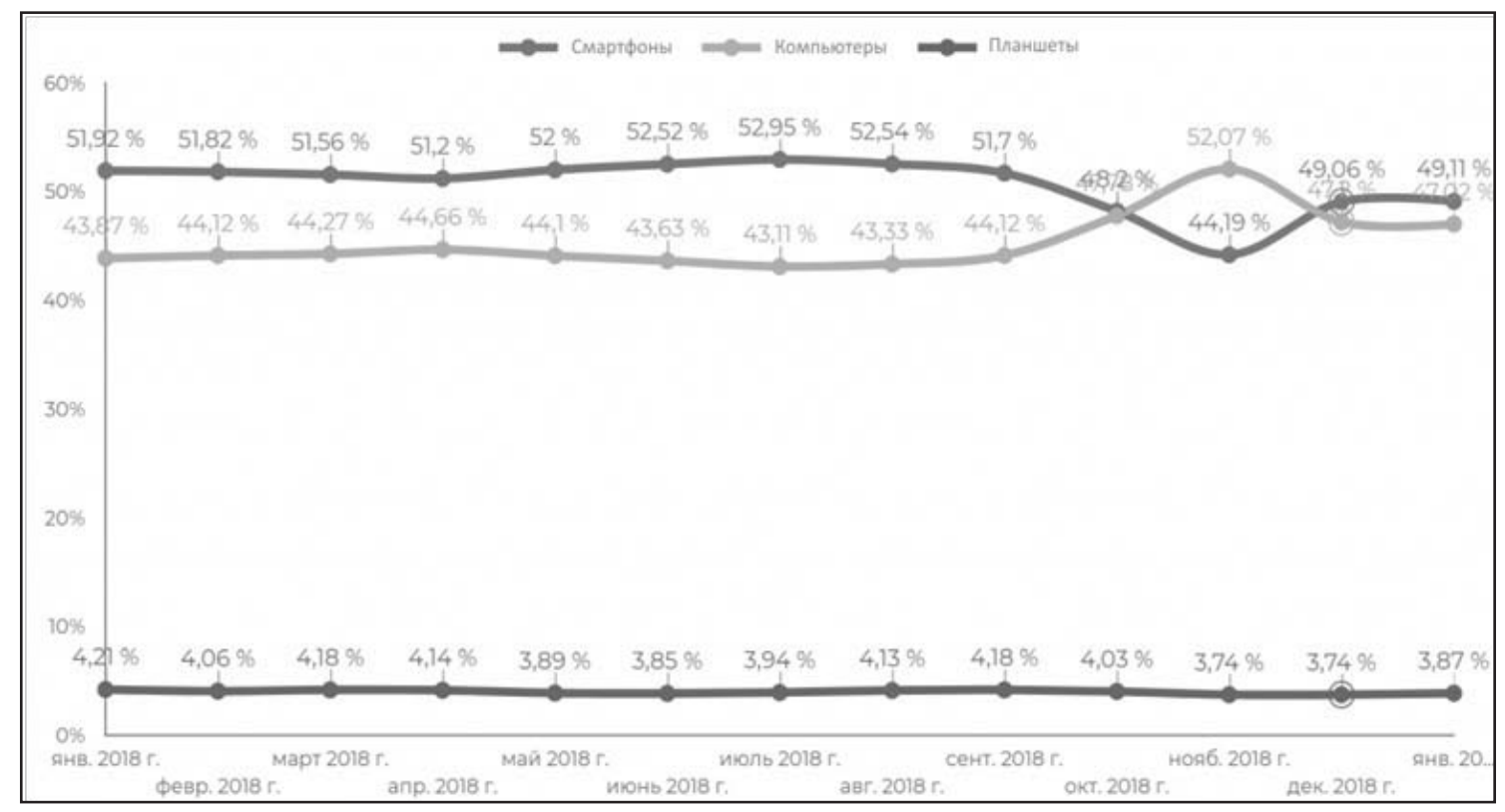

Рис. 3. Сравнительные данные по использованию смартфонов, компьютеров и планшетов для работы в сети Интернет

лионов сообщений в личных блогах: треть из них публикуются на сайтах, а остальные - в социальных сетях. 81\% (2020 г.) интернет-пользователей доверяют информации, найденной в личных блогах, а не СМИ. 75\% людей никогда не будут искать информацию на второй или следующей страницах Google.

Международным союзом электросвязи в развивающихся странах была разработана модель, согласно которой в предстоящие пять лет (с 2020 по 2025 гг.) количество молодых людей из возрастной группы 15-24 года, имеющих пятилетний или более опыт работы и общения в онлайн режиме, возрастет более, чем в два раза [4, с 18-19].

Это взаимодействие может носить разнообразный характер и иметь различные цели, от самых простых, связанных с потребностями личности, до самых сложных, связанных с поиском различного рода информации профессионального характера. Такая серьезная часть жизни и деятельности общества не может остаться вне поля зрения педагогической науки, занимающейся поиском возможностей и путей воспитания и обучения.

Актуальность исследования проблемы противодействия существующим угрозам и рискам в сети Интернет с педагогической точки зрения обусловлена рядом факторов.

Прежде всего, сеть Интернет занимает в жизни современного общества важное место, поскольку позволяет членам социума напрямую взаимодействовать с информационным полем, во многом определяющим успешность личности.

Другая причина необходимости внимательного отношения педагогических наук к взаимодействию личности и сети Интернет заключается в том, что это взаимодействие сопровождается разного рода рисками и угрозами, выявление, изучение и преодоление которых становится объектом педагогических исследований. Еще одна причина, по которой педагогика должна обратить пристальное внимание на деятельность личности в сети Интернет, заключается в том, что в ходе взаимодействия личности с информационным полем последнее оказывает влияние на личностную сферу, взаимодействует с личностными смыслами и способно осуществить изменения в личностной сфере. Такие изменения могут носить как эпизодический, так и глобальный характер, быть глубинными или поверхностными, но, в любом случае, это будут изменения, на которые необходимо обратить внимание.

Учитывая динамику увеличения количества детей и молодежи, которые проводят значительное время своей жизнедеятельности в сети Интернет с различными целями, и разделяя точку зрения многих ученых, которые рассматривают Интернет как один из основных факторов социализации современной молодежи, мы полагаем важным детальное исследование вопроса влияния интернет-угроз на человека, особенно, на молодых людей, и поиск путей организации обоснованной педагогической поддержки и сопровождения взаимодействия современного молодого человека и информационного поля, одним из проявлений которого является сеть Интернет. Это достаточно серьезная проблема, на которую 
обращают внимание на государственном уровне, о чем свидетельствует появление Федерального закона от 29.12.2010 № 436-Ф3 «О защите детей от информации, причиняющей вред их здоровью и развитию».

По данным Центра Безопасности Интернета в России, больше половины пользователей просматривают сайты с нежелательным контентом. По таким контентом мы понимаем ресурсы националистического и экстремистского характера, источники, привлекающие внимание к наркотическим веществам и алкоголю, к азартным играм, порносайты и сайты, содержащие сцены насилия.

Пользователь сети Интернет, попадая в сеть, становится уязвим в том плане, что лицом к лицу сталкивается с различными Интернет-угрозами, которые могут нанести вред в реальной жизни. Общение с мировым информационным пространством посредством мессенджеров и социальных сетей расширяется с невероятной скоростью, о чем свидетельствует тот факт, что, по оценкам аналитиков, в 2020 году в мире будет около 3.01 миллиарда пользователей социальных сетей по сравнению с 2.46 миллиарда в 2017 году. Facebook насчитывает около 2.22 миллиарда пользователей, a Instagram — около 1 миллиарда, Facebook Messenger и WhatsApp остаются самыми популярными приложениями для обмена сообщениями, причем более $50 \%$ интернет-пользователей используют их оба [3]. По оценкам международных экспертов, в среднем мы проводим в социальных сетях 2 часа 15 минут ежедневно [3]. Сейчас уже почти каждый третий ребенок в нашей стране выходит в интернет, и чем старше подростки, тем выше среди них доля «интернетчиков».

Сегодня детям доступно то, что лет пятнадцать назад было под силу лишь профессионалу или даже государству - создать собственную телестудию, получить картинку или музыку из-за тридевяти земель, поуправлять собственным мультфильмом. Во «взрослом» интернете, кроме этого, осуществляют платежи, потребляют электронные госуслуги, производят и продают контент.

Через интернет дети и подростки открывают для себя мир, формируют собственную личность. Интернет дает пользователю огромные возможности как высокотехнологичный источник коммуникации, как инструмент поиска и получения информации. Для того чтобы эффективно использовать этот инструмент, нужны как умения обращаться с ним, так и определенный жизненный опыт, позволяющий не захлебнуться в океане неограниченных возможностей интернета, вовремя разглядеть подводные камни, рифы и водовороты виртуального пространства. «Человек играющий» - это полифония возможностей, полифония миров, в которых эволюция движется по пути нарастания разнообразия идей, мировоззрений, культур и цивилизаций» [1, с.120]. Именно поэтому необходимо уделить особое внимание исследованию совокупности негативных воздействий, которые оказывает интернет-пространство на современного человека, особенно, на молодых людей.

Необходимо отметить, что диапазон научных проблем, рассматриваемых в рамках данной тематики, достаточно широк. Так, анализ литературы по проблеме позволил нам определить, что

- различные варианты негативных воздействий сети Интернет на «детей цифровой эпохи» проанализированы В. Гассером, Дж. Пэлфри [5] и др.;

- опасности, ожидающие детей и подростков в сети Интернет, и негативные последствия киберсоциализации исследовались В. Плешаковым [6];

- исследованиями угроз экстремизма в сети Интернет занимаются Н.Г. Дубовик, В.В. Стукалов, Е.В. Запорожец [7], М.М. Шакирьянов [8], а конкретно роль в этом процессе социальных сетей исследуется Д.В. Волковым, М.В. Рудик [9], А.В. Петряниным [10] и др.;

- педагогическими аспектами проблемы противодействия угрозам в сети Интернет занимаются Чусавитина Г.Н., Мусийчук М.В. [11], Недосекина А.Г. [12] и др.;

- возможности и риски в Интернете изучают С. Ливингстон [13], Л. Хэддон; риски, связанные с опасным медиасодержанием изучают Г. Михалева, А.И. Черников и др.;

- риски онлайн-среды в отношении детей исследуются Е. Золотовой, Т. Нестик, Е. Рассказовой, Г. Солдатовой и др.;

- системное рассмотрение негативных факторов, влияющих на пользователя персонального компьютера, исследуют В. Антонов, А.Н. Назаров, О.В. Казарин, Р.А. Шаряпов и др.;

- совокупность социальных рисков, вызванных появлением компьютера и сети Интернет, рассматривает А. Петренко-Лысак;

- виды интернет-мошенничества исследуют В. Самойлов, С.С. Хачатурова, Ю.П. Жихарева, Н. Широбокова и др.;

- особенности воздействия на интернет-потребителя изучают Н. Криковцева [17], Т.А. Воронцова, И.В. Евсеева и другие.

В рамках этой тематики мы встречаем такие понятия, как «угрозы», «риски», «вред», «вредоносное воздействие», которые различными исследователями интерпретируются по-разному. Прежде чем определить указанные термины применительно к нашему исследованию, мы отметим, что осуществленный нами анализ научной литературы различной тематической направленности позволил дифференцировать основные тенденции в классификации интернет-угроз. 
Признавая существование и безусловную связь упоминавшихся выше терминов, связанных с исследуемой проблемой, мы хотели бы разграничить данные понятия на смысловом уровне. Под «угрозой», вслед за другими исследователями, мы понимаем потенциальную возможность или неизбежность возникновения чего-либо опасного, неприятного, тяжелого. «Риск» трактуется как возможная опасность чего-либо, то есть, осознание, осмысление опасности чего-либо. Проанализировав исследования поведения людей в сети Интернет [3, 19, 20], а также мнение зарубежных и отечественных ученых по этой проблеме [4, 6, 7-17], мы придерживаемся следующей классификации рисков, представленной на рис. 4.

«Вред» понимается как «физическое повреждение и убытки, причинённые здоровью людей и имуществу или окружающей среде» [18, с.84]. «Вредоносное воздействие» трактуется как воздействие, несущее за собой физические повреждения, убытки, наносящее ущерб здоровью, имуществу или окружающей среде. То есть, если проследить все цепочку логически, то получается структура, представленная на рис.5.

Если проследить всю терминологическую цепочку, то получается, что существуют угрозы, они существуют независимо от пользователя, если, конечно, он не сам их создает. Если пользователь относится к угрозам сознательно, то есть осознает их, мы можем говорить о рисках, которые осознаются пользователем, то есть осознание риска - это осознание той угрозы, которая может представлять опасность для пользователя. Как правило, угроза осознается взрослыми людьми, хотя бывают ситуации, когда угроза является завуалированной, скрытой, замаскированной, тогда она может быть риском и для человека, осознающего существование угроз. Именно в связи с этим мы полагаем, что если мы говорим о детях, то следует говорить об угрозах, а если мы говорим о взрослых, то следует рассуждать о рисках как осознанных угрозах, но не всегда распознаваемых. В этом нам представляется принципиальная разница между рисками и угрозами во взаимодействии с сетью Интернет. Более детальная классификация угроз представлена на рис.6.

О чем следует говорить в данном случае, если речь идет о студентах, о возрастной прослойке, находящейся между детьми и взрослыми в возрастном плане? Речь идет, прежде всего, об учете возрастных и социальнопсихологических особенностей студента, свойственных возрасту 17-25 лет:

- период сложнейшего структурирования интеллекта; наивысшая скорость оперативной памяти и переключения внимания, решения вербально-логических задач; все эти особенности, безусловно, способствуют поиску информации и эффективной работе в сети, однако, переключение внимания может быть причиной отклонения от траектории поиска информации;

- активное развитие нравственных и эстетических чувств, становление и стабилизация характера, овладение всей палитрой социальных ролей взрослого человека: гражданских, профессионально-трудовых и т.д.; это усугубляет угрозы, поскольку становление чувств и идеалов свидетельствует о том, что эта сфера еще достаточно зыбкая, восприимчивая к изменениям, находящаяся в стадии становления, а, следовательно, очень подвержена влиянию извне; неизвестно, будут ли личностные смыслы обучающегося в состоянии противостоять тому, что будет пытаться нарушить их основы;

- изменения в мотивационной сфере, в системе ценностных ориентаций, связанные со становлением характера, а также интенсивное формирование специальных способностей в связи с профессиональным становлением; это означает повышенное внимание и стремление к поиску новой информации и недостаточную пока стабильность ценностной сферы;

- усиление сознательных мотивов поведения (целеустремленность, решительность, настойчивость, самостоятельность, инициатива, умение владеть собой); эти качества могут способствовать противостоянию угрозам, если они достаточно развиты;

- повышение интереса к моральным проблемам (образу жизни, долгу, любви, верности, чести, честности и т.д.); это может быть сдерживающим фактором и ориентирующим на осторожность и внимание при работе в сети;

- немотивированный и неоправданный риск, неспособность прогнозировать последствия собственных действий; углубленный самоанализ и постоянная самооценка путем сравнения идеального «я» с реальным, это самая тревожная особенность в плане способности и готовности противостоять угрозам.

Таким образом, проведенный анализ позволил нам выделить особенности студенческого возраста, способствующие формированию способности и готовности противостоять угрозам при работе в сети Интернет, а также снижающие эффективность противостояния этим угрозам.

Все это, так или иначе, определяет особенности информационно-образовательной деятельности студента в интернет-пространстве, которая по своему содержанию может быть представлена следующим образом, как показано на рис.7.

В результате рассмотрения всего спектра проблем, связанных с взаимодействием обучающегося и интер- 


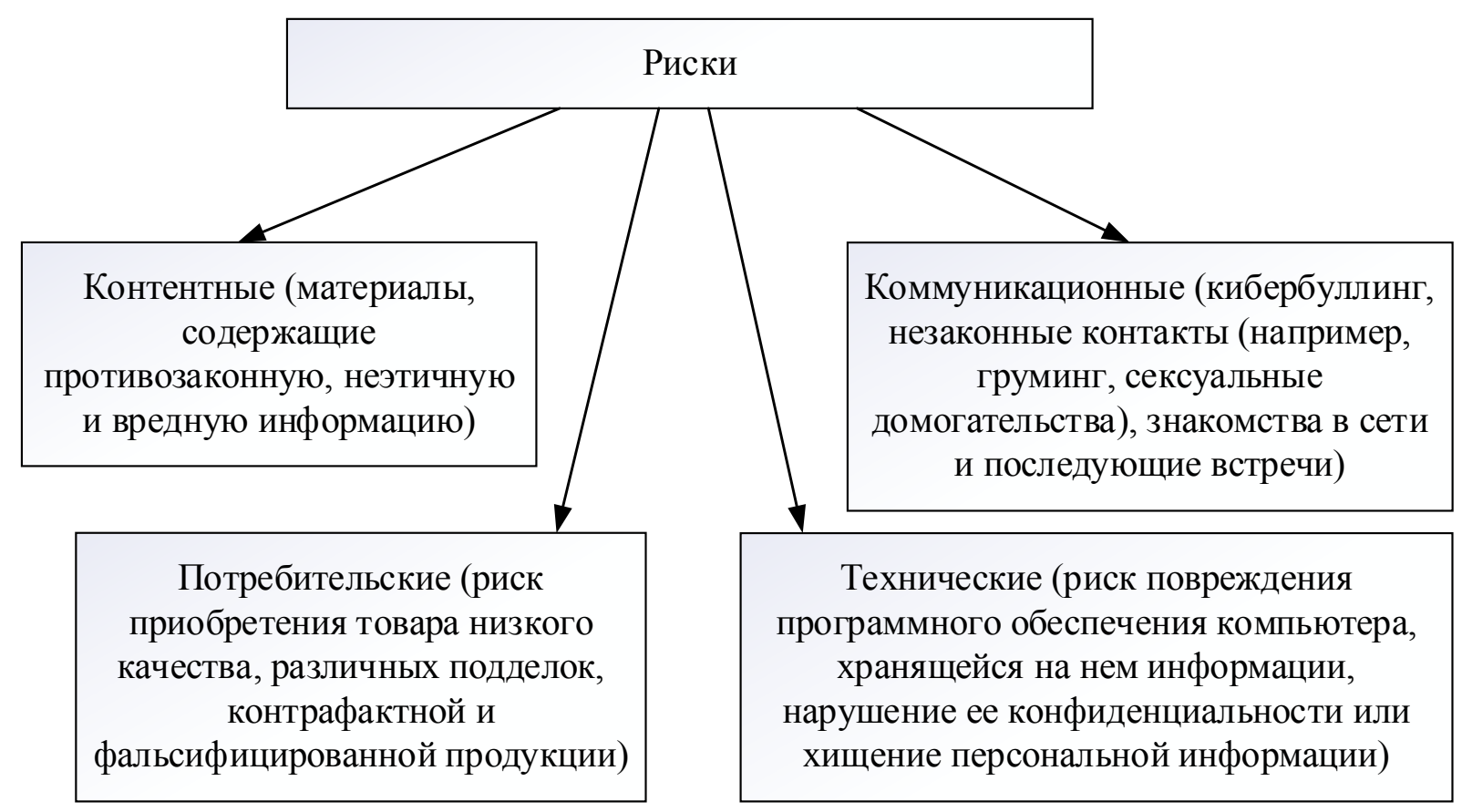

Рис. 4. Классификация рисков при взаимодействии с сетью Интернет

Существующие угрозы при взаимодействии с интернет-пространством

Личностная сфера человека, личностные смыслы

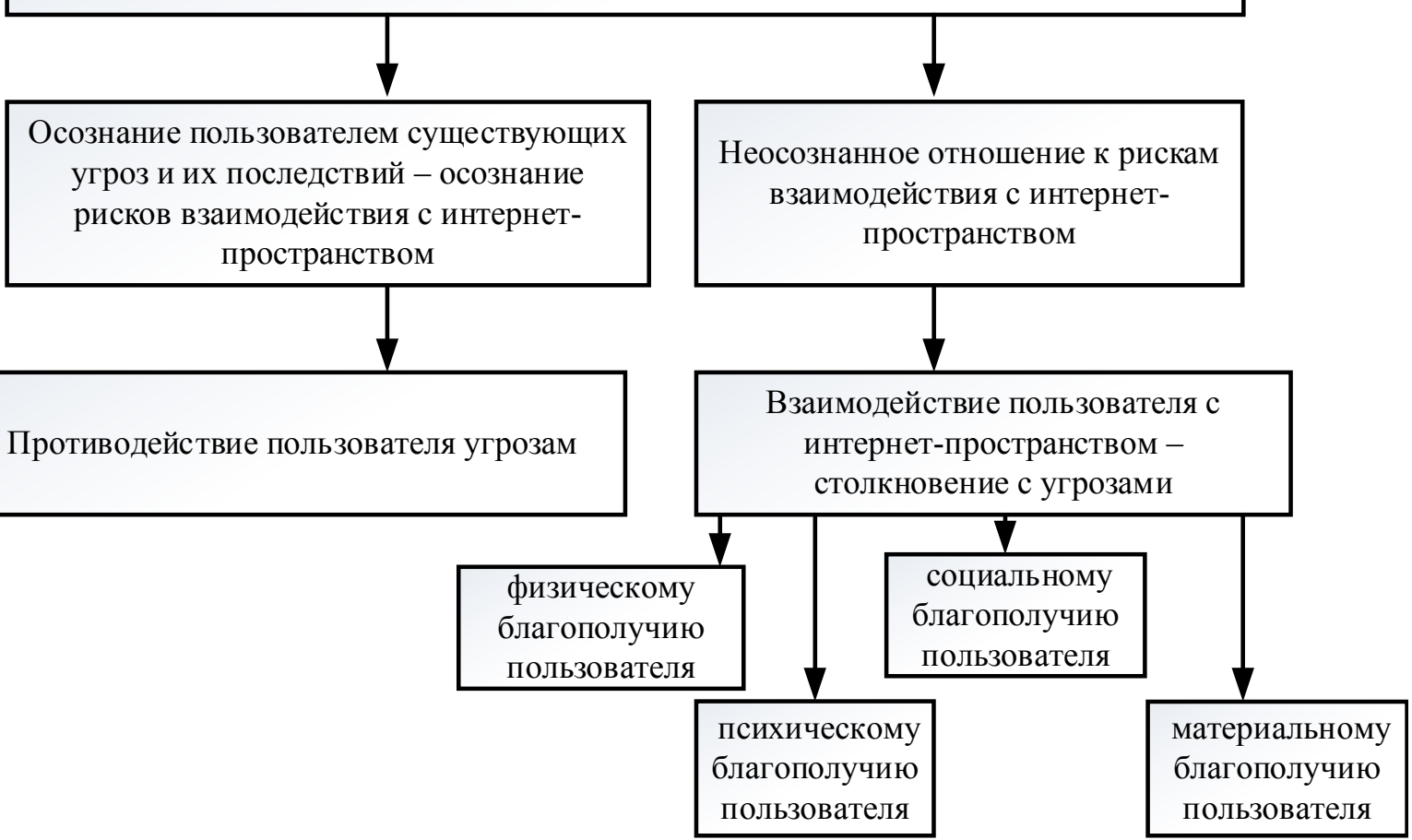

Рис. 5. Угрозы и риски в системе взаимодействия пользователя с интернет-пространством 


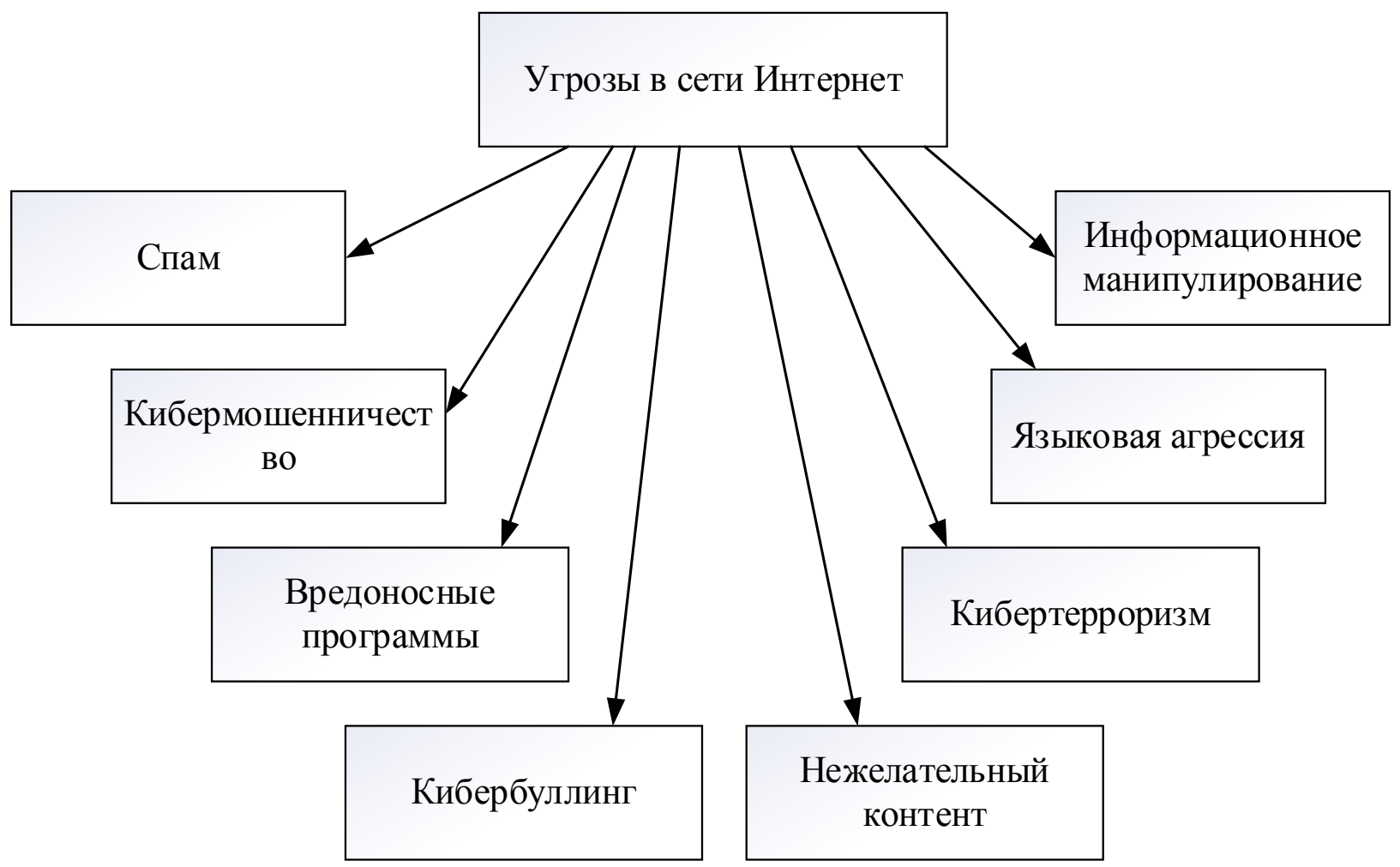

Рис. 6. Классификация угроз в сети Интернет

Типы информационно-образовательной деятельности обучающегося высшей школы в сети Интернет

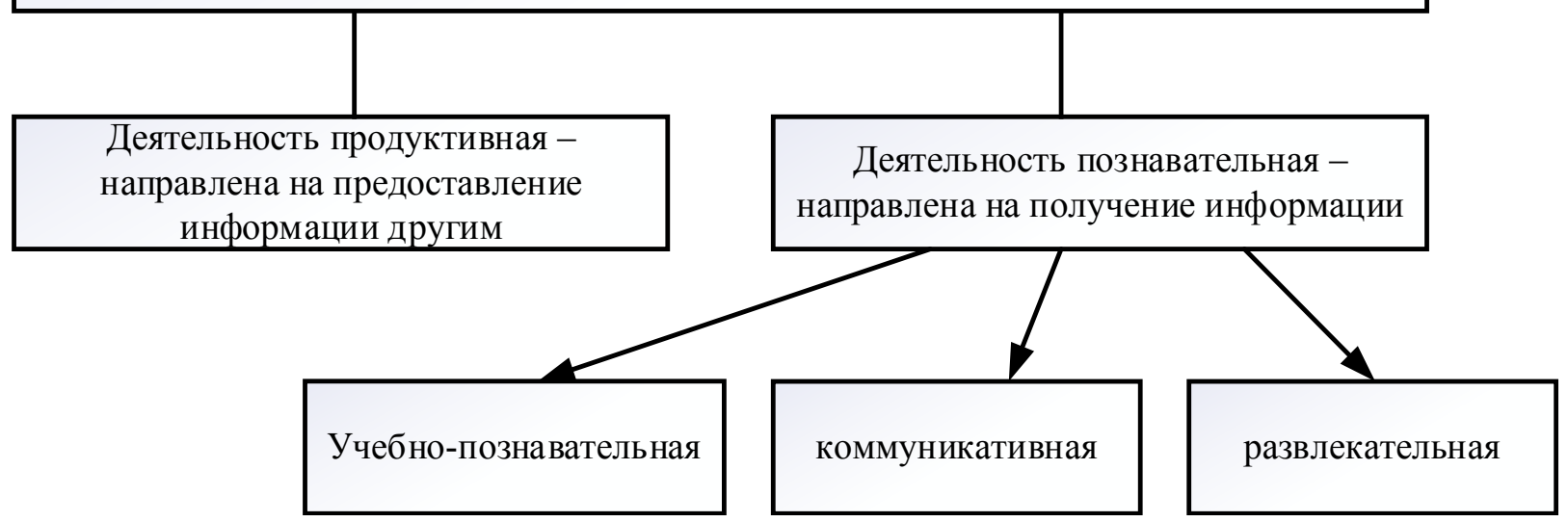

Рис. 7. Типы информационно-образовательной деятельности обучающегося высшей школы в сети Интернет

нет-пространства, в ракурсе педагогической науки мы пришли к выводу о том, что:

- контент интернет-пространства представляет собой сложную сферу, на которую невозможно оказать какое-либо влияние; рычаги регулирования в данном случае есть, но они находятся у государства, реализующего свои попытки управления им через специальные службы;

- студенчество является достаточно уязвимой частью интернет-пользователей, поскольку элемен- ты личностной сферы, способные противостоять угрозам интернет-пространства, находятся в стадии становления;

- многообразие видов деятельности в интернетпространстве способствует успешной и эффективной учебно-познавательной деятельности, закрепляя за интернет-пространством функцию главного фактора успешной учебной деятельности современного студента;

- необходимо педагогическое сопровождение и 
поддержка пользователя сети Интернет, для реализации которых необходима разработка специальных технологий, методик, форм и видов деятельности, ориентированных на формирование представления об угрозах в сети, осознание рисков, с которыми может столкнуться пользователь при поиске необходимой информации, формирование и развитие компетенций, позволяющих пользователю управлять своей деятельностью в сети Интернет, обеспечивать ее эффективность.

Что можно было бы предложить в педагогическом плане в качестве реального педагогического сопровождения и поддержки? Это могут быть следующие виды педагогической работы с обучающимися высшей школы:

- самая первая и главная педагогическая мера это профессиональная и научно обоснованная ориентировка тех, кто работает с молодежью, на решение указанных проблем, обсуждение проблем формирования устойчивости личности к негативным формам воздействий в сети Интернет на занятиях с бакалаврами и магистрами, на методологических семинарах с аспирантами, молодыми преподавателями;

- модернизация и разработка новых учебных программ дисциплин высшего и послевузовского профессионального образования, курсов повышения научной и профессиональной квалификации с учетом научно-методических наработок в области противодействия угрозам и рискам работы в сети Интернет; буквально в каждой учебной дисциплине, связанной с информационными технологиями и их использованием в учебно-воспитательном процессе необходимо акцентировать внимание на риски и угрозы при работе в сети Интернет, на умение ими управлять и с ними справляться, студентов необходимо научить, каким образом этому противостоять и как на это реагировать, хотя бы попытаться дать алгоритмы действий в ситуации угрозы, научить распознавать угрозу и реагировать на нее;
- введение новых тем по вопросам противодействием угрозам в сети Интернет в образовательные программы в части регионального компонента и дисциплин по выбору для профильных специальностей и направлений высшего образования, системы послевузовского образования научно-педагогических кадров;

- актуализация тематики научно-исследовательской работы студентов, молодых ученых, преподавателей и аспирантов с целью профилактики негативного воздействия отдельных факторов интернет; введение проблемных тем в научную деятельность студентов обеспечит понимание ими проблемы совершенно на ином уровне, они смогут «пережить» проблему, что, возможно, будет способствовать формированию у них иммунитета к существующим в сети угрозам;

- использование материалов об угрозах и рисках в сети Интернет при курсовом и дипломном проектировании студентов в качестве основы формирования устойчивого противодействия негативным факторам в сети Интернет, начиная с младших курсов, что может способствовать формированию устойчивой способности противостоять рискам и угрозам к старшим курсам;

- организация и проведение серьезной, глубокой разъяснительной работы со студентами, позволяющей обратить их внимание на проблему, сформировать необходимые компетенции в ходе обсуждения и обмена мнениями; в данном случае массовые разъяснительные мероприятия не будут иметь никакой силы, реальную пользу может принести только общение в повседневной обстановке, выяснение их отношения к этим проблемам, ориентировка на внимательное отношение к собственной личностной сфере.

Таким образом, могут быть усилены педагогические аспекты проблемы профилактики и противодействия деструктивным угрозам личности студентов в сети Интернет.

\section{ЛИТЕРАТУРА}

1. Асмолов А.Г. Оптика просвещения: социокультурные перспективы / А.Г. Асмолов. - М.: Просвещение, 2012. - 447 с.

2. Бурлаков И. Homo Gamer. Психология компьютерных игр. - М.: Издательство «Независимая фирма Класс», 2000.

3. https://www.iguides.ru/main/other/internet_statistika_sotsialnye_seti/

4. Черных Е.А. Анализ классификаций угроз в Интернете / Е.А. Черных // Электронный научно-публицистический журнал «Homo Сyberus». - 2016. - № 1. [Электронный ресурс] - Режим доступа: http://journal.homocyberus.ru/chernih_e_analis_ugroz_v_internere, свободный. - Загл. с экрана.

5. Пелфри Дж. Дети цифровой эпохи / Пелфри Дж., Гассер У. [пер. с англ. Н. Яцюк] - М. : Эксмо, 2011 - 368 с.

6. Плешаков В.А. Теория киберсоциализации человека : монография / Под ред. А.В. Мудрика. - М. : МПГУ; «Ноmo Сyberus», 2011. - 400 c.

7. Стукалов В.В., Запорожец Е.В. Проблемы противодействия экстремизму в сети Интернет // Общество и право. 2016. № 4 (58).

8. Шакирьянов М.М. Пути повышения эффективности расследования преступлений экстремисткой направленности в сети // Вестник Казанского юридического института МВД России. 2018. № 4(34). 
9. Рудик М.В., Волков Д.В. Социальные сети как средство распространения экстремизма // Вестник Краснодарского университета МВД России. 2017. № 2 (36).

10. Петрянин А.В. Уголовно-правовые, оперативно-разыскные и криминалистические механизмы противодействия экстремизму в телекоммуникационных сетях и сети Интернет: на примере статьи 280 УК РФ // Вестник Нижегородской академии МВД России. 2016. № 1 (13).

11. Чусавитина Г.Н., Мусийчук М.В. Педагогические аспекты проблемы противодействия угрозам в сети интернет // Мир науки. Педагогика и психология. 2017. №6. URL: https://cyberleninka.ru/article/n/pedagogicheskie-aspekty-problemy-protivodeystviya-ugrozam-v-seti-internet (дата 0бращения: 18.06.2020).

12. Недосекина А.Г. Формирование эстетического идеала как средство профилактики киберэкстремизма // Фундаментальные исследования. 2014. №12. C. 1083-1088.

13. Livingstone S. In their own words: what bothers children online? / S. Livingstone, L. Kirwil, C. Ponte \& E. Staksrud // EU Kids Online, London School of Economics \& Political Science, London, UK. - 2013. [Электронный ресурс] - Режим доступа: http://www.Ise.ac.uk/media\%40lse/research/EUKidsOnline/Home.aspx

14. Livingstone S. Kids online: opportunities and risks for children. / Livingstone Sonia, Haddon Leslie [Электронный ресурс] - Режим доступа: http://eprints.Ise. ac.uk/30130/1/Kids_online_introduction_(LSERO).pdf

15. Михалева Г.В. Онлайн-риски и проблемы защиты детей в современном британском медиаобразовании / Г. В. Михалева // Диалог. - 2014. - № 6 (30). C. 66-75.

16. Солдатова Г.У. Цифровая компетентность подростков и родителей. Результаты всероссийского исследования / Г.У. Солдатова, Т.А. Нестик, Е.И. Рассказова, Е.Ю. Зотова. — М.: Фонд Развития Интернет, 2013. — 144 с.

17. Криковцева Н.0. Інтернет-маркетинг: стратегія і тактика [Текст] : монографія / Н.0. Криковцева, А.С. Цеомашко; Донец. нац. ун-т економіки і торгівлі ім. Михайла Туган-Барановського. - Донецьк : ДонНУЕТ, 2012. - 236 с. - С. 229-236.

18. Березуцький В.В. Тлумачний словник нормативних термінів із дисципліни «Безпека життєдіяльності» : навч. посіб. / В.В. Березуцький, Л.А. Васильковець; Нац. техн. ун-т «Харк. політехн. ун-т». - Х. : Підручник НТУ «ХПІ», 2013. - 88 с.

19. Отчет Международного союза электросвязи «Измерение информационного общества» [Электронный ресурс] - Режим доступа: www.itu.int/go/mis2013

20. Устав Всемирной организации здравоохранения. [Электронный ресурс] - Режим доступа: http://apps.who.int/gb/bd/PDF/bd47/RU/constitution-ru. pdf?ua $=1$

( К Курейчик Виктор Михайлович (vmrureychik@sfedu.ru), Писаренко Вероника Игоревна (vero19671993@gmail.com).

Журнал «Современная наука: актуальные проблемы теории и практики»

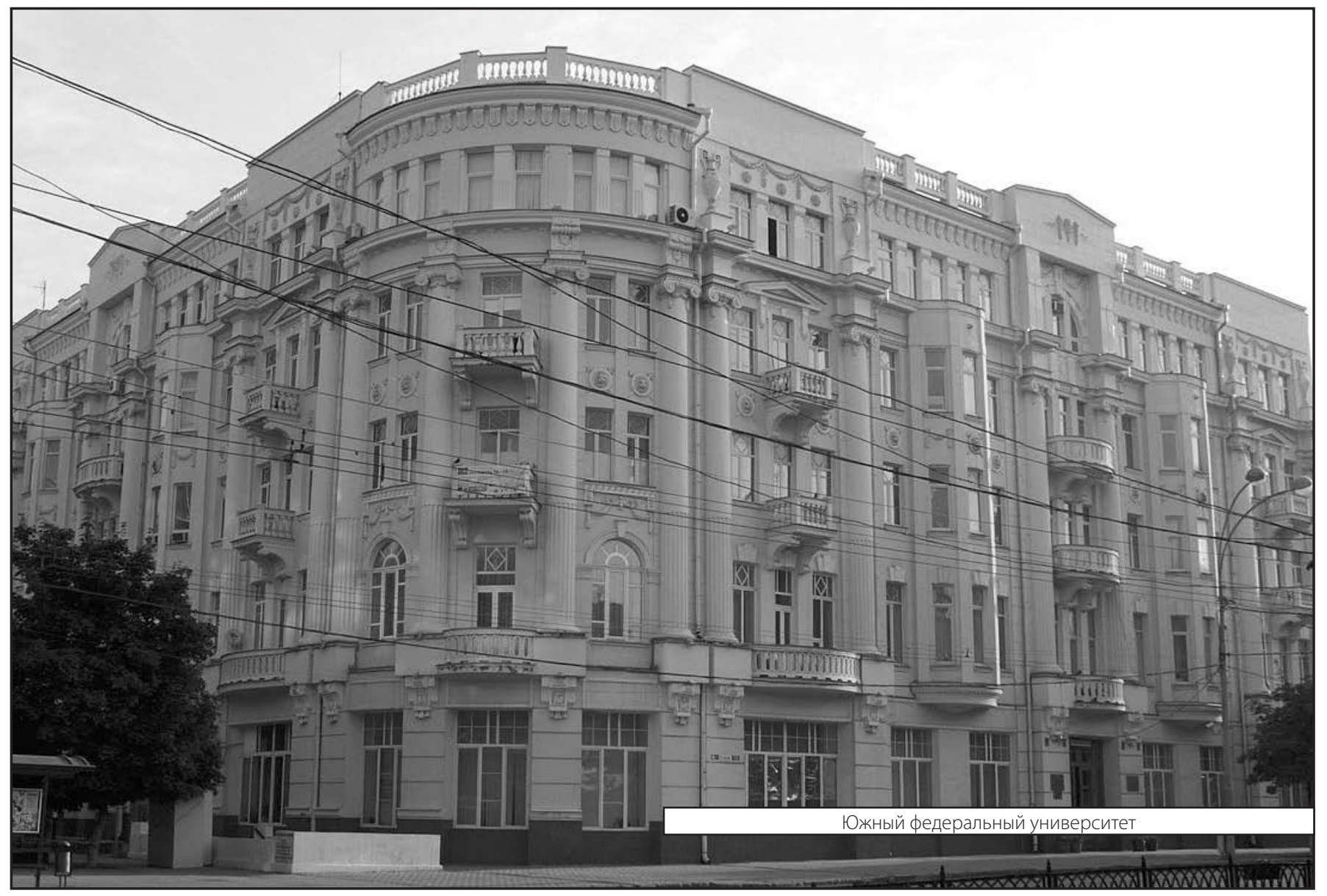

